\title{
Bacterial community structure associated with white band disease in the elkhorn coral Acropora palmata determined using culture-independent 16S rRNA techniques
}

\author{
Olga Pantos ${ }^{1}$, John C. Bythell ${ }^{2, *}$ \\ ${ }^{1}$ Centre for Marine Studies, University of Queensland, St. Lucia, Brisbane 4072, Queensland, Australia \\ ${ }^{2}$ School of Biology, Newcastle University, Ridley Building, Newcastle upon Tyne NE1 7RU, UK
}

\begin{abstract}
Culture-independent molecular (16S ribosomal RNA) techniques showed distinct differences in bacterial communities associated with white band disease (WBD) Type I and healthy elkhorn coral Acropora palmata. Differences were apparent at all levels, with a greater diversity present in tissues of diseased colonies. The bacterial community associated with remote, non-diseased coral was distinct from the apparently healthy tissues of infected corals several $\mathrm{cm}$ from the disease lesion. This demonstrates a whole-organism effect from what appears to be a localised disease lesion, an effect that has also been recently demonstrated in white plague-like disease in star coral Montastraea annularis. The pattern of bacterial community structure changes was similar to that recently demonstrated for white plague-like disease and black band disease. Some of the changes are likely to be explained by the colonisation of dead and degrading tissues by a micro-heterotroph community adapted to the decomposition of coral tissues. However, specific ribosomal types that are absent from healthy tissues appear consistently in all samples of each of the diseases. These ribotypes are closely related members of a group of $\alpha$-proteobacteria that cause disease, notably juvenile oyster disease, in other marine organisms. It is clearly important that members of this group are isolated for challenge experiments to determine their role in the diseases.
\end{abstract}

KEY WORDS: Molecular $\cdot$ Microbial ecology $\cdot$ Coral disease $\cdot$ White band disease $\cdot$ WBD

\section{INTRODUCTION}

White band disease (WBD) is a pan-tropical coral disease that has had a devastating impact on the ecology of Caribbean reefs, where it has severely affected 2 of the most important framework-building species, Acropora palmata and A. cervicornis (Gladfelter 1982, Peters 1993, Bythell et al. 2000, Aronson \& Precht 2001, Aronson et al. 2002). WBD was first reported by Gladfelter (1982) from a large-scale epizootic that began in the Caribbean in the mid-1970s. A second form (Type II) was documented later (Ritchie \& Smith 1995). Both types are characterised by a progressive lesion that encircles the branches, typically starting at the base and progressing towards the tips, and showing a sharp demarcation between apparently healthy tissues and bare skeleton. The rate of tissue loss varies from a few $\mathrm{mm}$ to several $\mathrm{cm} \mathrm{d}^{-1}$ (Antonius 1981, Ritchie \& Smith 1998), exposing a band of bare skeleton 5 to $10 \mathrm{~cm}$ wide that subsequently becomes colonised by filamentous algae and other epibionts (see Fig. 1). Lesions of Type II WBD are more frequently found to start at the tips or middle of branches, progressing in either direction from a point of infection, and are characterised by a variable-width band of reduced pigmentation (bleaching) preceding the tissue loss (Ritchie \& Smith 1995).

The aetiology of this disease remains unresolved. Previous studies have identified differences in the bacterial community associated with the surface 
mucopolysaccharide layer (SML) of healthy and diseased tissues from WBD Type II affected Acropora cervicornis colonies (Ritchie \& Smith 1995), and gram-negative bacteria have been found within healthy and diseased tissues of both $A$. cervicornis and $A$. palmata colonies affected by WBD Type I (Peters et al. 1983). Bacterial communities so far identified in association with the SML and tissues of diseased colonies have not been fully characterised and there is no direct evidence to indicate that they are responsible for the disease (Antonius 1981, Gladfelter 1982, Peters et al. 1983, Ritchie \& Smith 1995, 1998). However, recent studies indicate that a causal agent of WBD Type II may have been identified (G. W. Smith pers. comm.).

In this study we describe the bacterial community structure associated with the tissues of healthy Acropora palmata colonies and those affected by WBD Type I, and identify possible causal agents using a range of molecular bacterial 16S rDNA techniques. Whilst this approach does not positively identify casual agents, by first identifying the community composition through sequence analysis of 16S rRNA gene fragments, culture conditions can be optimised to target potential pathogens (i.e. those always found in diseased tissue but extremely rare in, or absent from, non-diseased tissue; Relman 1998), which can then be used to satisfy Koch's postulates (Fredricks \& Relman 1996) to support the assertion of their involvement in the disease process.

\section{MATERIALS AND METHODS}

Sample collection. Samples of Acropora palmata demonstrating the classic signs of WBD Type I were collected from several reefs in Barbados (May and June 2000). Sterile chisels were used to take $2 \times 2 \mathrm{~cm}$ samples of the coral tissues to a depth of approximately $0.5 \mathrm{~cm}$. Four sample types were collected for each lesion (Fig. 1): (1) 'Control' samples (CON) were taken from an area of apparently healthy tissue on the diseased colony 8 to $10 \mathrm{~cm}$ from the lesion boundary; (2) diseased tissue samples (DIS) were taken from the lesion boundary at the interface between healthy tissue and bare skeleton; (3) exposed skeleton was collected $5 \mathrm{~cm}$ from the lesion boundary (SKEL); and (4) healthy tissues were taken from remote colonies on the same reefs that showed no signs of disease (REM).
Samples were placed into sterile universal tubes and stored in $100 \%$ ethanol at $-20^{\circ} \mathrm{C}$ until processed.

DNA isolation. Samples were homogenised to a fine powder using liquid nitrogen and sterile pestle and mortars. Approximately $200 \mathrm{mg}$ of ground sample was added to Q-biogene FastDNA-Blue homogenisation tubes (Q-biogene), with $500 \mu$ l hexadecyltrimethylammonium bromide (CTAB) extraction buffer (equal volumes of $10 \%$ CTAB in $0.7 \mathrm{mmol} \mathrm{l}^{-1} \mathrm{NaCl}$, with $240 \mathrm{mmol} \mathrm{l}^{-1}$ potassium phosphate buffer $\mathrm{pH}$ 8.0) and $500 \mu \mathrm{l} \mathrm{phenol/chloroform/isoamyl} \mathrm{alcohol,} \mathrm{and} \mathrm{vor-}$ texed. Samples were lysed at $6.5 \mathrm{~m} \mathrm{~s}^{-1}$ for $30 \mathrm{~s}$ in a Qbiogene FastPrep FP120 homogeniser and centrifuged at $16000 \times g$ for $5 \mathrm{~min}$ at $4^{\circ} \mathrm{C}$. The top aqueous layer was removed and placed in a fresh tube with equal volume of chloroform:isoamyl alcohol, mixed by vortexing and centrifuged at $16000 \times g$ for $5 \mathrm{~min}$ at $4^{\circ} \mathrm{C}$. The top aqueous layer was removed and placed in a fresh tube with 2 volumes of $30 \%$ polyethylene glycol (PEG) $8000(\mathrm{w} / \mathrm{v})$ in $1.6 \mathrm{mmol} \mathrm{l} \mathrm{l}^{-1} \mathrm{NaCl}$, mixed briefly by vortexing and left at room temperature for $2 \mathrm{~h}$. The mixture was centrifuged at $18000 \times g$ for $10 \mathrm{~min}$, the supernatant discarded and the pellet washed with $70 \%$ ethanol $\left(-20^{\circ} \mathrm{C}\right)$. The pellet was air-dried and suspended in $50 \mu \mathrm{l}$ TE buffer $\left(10 \mathrm{mmol} \mathrm{l}^{-1}\right.$ Tris-HCl/ $1 \mathrm{mmol} \mathrm{l}^{-1}$ EDTA, pH 7.4).

PCR conditions. 16S rRNA genes were amplified from DNA extracts by PCR using universal bacterial primers manufactured by Interactiva (www.interac- 
tiva.de/). The primers pA (8F) (5'-AGA GTT TGA TCC TGG CTC AG-3') and pH' (1542R) (5'-AAG GAG GTG ATC CAG CCG CA-3') were used for cloning and pC (314F) (5'-CCT ACG GGA GGC AGC AG-3') and $\mathrm{pE}^{\prime}$ (928R) (5'-CCG TCA ATT CCT TTG AGT TT-3') were used for denaturing gradient gel electrophoresis (DGGE) analysis according to Edwards et al. (1989). The forward primer $\mathrm{pC}$ contained a 40 base guanine and cytosine (GC)-clamp (5'-CGC CCG CCG CGC GCG GCG GGC GGG GCG GGG GCA CGG GGG G$3^{\prime}$ ) at its $5^{\prime}$ end to stabilise the melting behaviour of the DNA fragments during DGGE (Rölleke et al. 1996, 1998). PCR reactions (100 l) were carried out using $1.5 \mathrm{mmol} \mathrm{l}^{-1} \mathrm{MgCl}_{2}, 0.2 \mathrm{mmol} \mathrm{l^{-1 }}$ dNTP (Promega), $0.5 \mathrm{mmol} \mathrm{l}^{-1}$ each primer, and $5 \mathrm{U}$ of Taq DNA polymerase (Q-biogene). Amplification was carried out using a Hybaid PCR Express thermal cycler. Optimised PCR conditions described by Pantos et al. (2003) were used, including an initial denaturation 'hotstart' of 7 min at $94^{\circ} \mathrm{C}$ used with GC-clamped primers, followed by cooling to $80^{\circ} \mathrm{C}$ when the Taq DNA polymerase was added. A 'touchdown' protocol was then used in which the annealing temperature was decreased from $65^{\circ} \mathrm{C}$ by $1^{\circ} \mathrm{C}$ every second cycle until a touchdown temperature of $55^{\circ} \mathrm{C}$, at which temperature 6 additional cycles were carried out. Denaturing was carried out at $94^{\circ} \mathrm{C}$ for $1 \mathrm{~min}$, primer annealing was at the appropriate temperature for $1 \mathrm{~min}$, and primer extension at $72^{\circ} \mathrm{C}$ for $3 \mathrm{~min}$. This was followed by a final step at $72^{\circ} \mathrm{C}$ for 10 min and cooling to $4^{\circ} \mathrm{C}$. For reactions using primers without the GC-clamp ( $\left.\mathrm{pA} / \mathrm{pH}^{\prime}\right)$ the touchdown reaction was used following the initial denaturing step at $95^{\circ} \mathrm{C}$. PCR products were analysed by agarose gel electrophoresis $(1.6 \% \mathrm{w} / \mathrm{v}$ agarose) stained with ethidium bromide and visualised using a UV transilluminator.

Clone libraries and amplified ribosomal DNA restriction analysis (ARDRA) screening. Clone libraries were prepared from 2 DIS and 2 REM samples collected from Barbados, and screened by ARDRA following the protocol described by Cooney et al. (2002). PCR products using primers $\mathrm{pA} / \mathrm{pH}^{\prime}$ were gel purified using a $1.6 \%(\mathrm{w} / \mathrm{v})$ agarose gel and the QIAquick gel extraction kit (Qiagen). The purified product was inserted into the pGEM-T vector system (Promega) and transformed into Escherichia coli JM109 cells according to the manufacturer's instructions. A total of 95 clones containing the 16S rRNA gene inserts were selected from each sample, and lysates were prepared from each by mixing a loopful of biomass with $50 \mathrm{l} \mathrm{TE}$ buffer and boiling for 3 min followed by freezing. Each lysate (1 l) was amplified with the primers pUCF (5'GTA AAA CGA CGG CCA GT-3') and pUCR (5'-CAG GAA ACA GCT ATG AC-3') using the touchdown PCR protocol. Restriction analysis was carried out on the amplification products using the restriction enzymes HaeIII and RsaI (Promega) (12 l of PCR product, $2 \mu \mathrm{l}$ of restriction buffer, $0.2 \mu \mathrm{l}$ of BSA, $0.07 \mu \mathrm{l}$ of HaeIII, $0.1 \mu \mathrm{l}$ of Rsal and $5.63 \mu \mathrm{l}$ of $\mathrm{H}_{2} \mathrm{O}$ for $3 \mathrm{~h}$ at $37^{\circ} \mathrm{C}$ ). Restriction fragments were resolved by agarose gel electrophoresis $(3 \% \mathrm{w} / \mathrm{v})$, stained with ethidium bromide and visualised using a UV transilluminator. Clones were grouped based on their restriction patterns and representatives from each group were sequenced.

Denaturing gradient gel electrophoresis (DGGE). DGGE was performed using the D-Code universal mutation detection system (Bio-Rad). PCR products were formed employing a nested protocol. DNA extracts were initially amplified in $50 \mu \mathrm{l}$ reactions using the external primers $\mathrm{pA}$ and $\mathrm{pH}^{\prime}$. The products were purified using the QIAquick PCR purification kit (Qiagen) and diluted 1:100 with PCR-grade water and amplified in $100 \mu \mathrm{l}$ reactions using the internal DGGE primers $\mathrm{pC}$ and $\mathrm{pE}^{\prime}$. Hotstart and touchdown reaction conditions were used as described. Approximately $15 \mathrm{\mu l}$ of the nested PCR product was resolved on $6 \%$ (w/v) polyacrylamide gels that contained a 30 to $60 \%$ denaturing gradient for $5 \mathrm{~h}$ at $60^{\circ} \mathrm{C}$, at a constant voltage of 180V. Gels were stained with SYBR Green 1 (Sigma) and visualised using a UV transilluminator.

Sequencing and phylogenetic analysis. 16S rDNA amplicons were purified with the QIAquick PCR purification kit (Qiagen) and sequenced using an ABI Prism DNA sequencer (Molecular Biology Unit, University of Newcastle upon Tyne, UK). Sequence data was edited using Chromas (McCarthy 1996) and examined for errors using ProSeq (Filatov 2001). Partial 16S rRNA gene sequences obtained using $\mathrm{pE}^{\prime}$ (approximately from nucleotide 478-928, corresponding to Escherichia coli numbering) were submitted to DDBS/EMBL/ GenBank databases under the accession numbers AY323132-AY323197. Sequences were submitted to BLAST at NCBI (National Centre for Biotechnology Information) to determine percentage similarity with known 16S rDNA sequences. Sequence similarity of 97 to $100 \%$ can be considered to approximate to a species level similarity, 93 to $96 \%$ was accepted as a genuslevel similarity, and $<92 \%$ was considered to be below genus level similarity (Stackebrandt \& Goebel 1994). Sequences for phylogenetic analysis were aligned using Phylogenetic editor (Chun 1996), and phylogenetic trees were constructed using TREECON (Van de Peer 1994). Trees were inferred from aligned sequences using neighbour-joining algorithms (Saitou \& Nei 1987), and evolutionary distances were generated as described by Jukes \& Cantor (1969). LIBSHUFF analyses were used to compare clone libraries created from the different samples to establish levels of similarity in the bacterial 16S rRNA gene diversity present (Singleton et al. 2001). Frequency of clone group sequences was 
based on ARDRA screening which will tend to overestimate coverage of high sequence similarities.

\section{RESULTS}

\section{Bacterial community structure of healthy and diseased tissues}

The majority of coral-associated bacteria identified by $16 \mathrm{~S}$ rDNA sequence analysis and BLAST search were most closely related to bacteria previously described from marine environments, and there was little or no evidence of bacteria of human or terrestrial origin (Tables 1 \& 2). Clone libraries created from the DIS tissues at the lesion boundary showed greater ribosomal sequence diversity than the tissues of REM. These differences were shown to be highly significant $(p<0.01)$ using LIBSHUFF analysis, which determines the similarities in levels of sequence diversity across all levels (Singleton et al. 2001). At a fixed level of $97.5 \%$ sequence similarity (450 bp), which approximates a species-level identity (Stackebrandt \& Goebel 1994), 22 distinct ribosomal types (ribotypes) were detected

Table 1. Acropora palmata. Bacterial 16S rDNA sequences obtained from 2 independent healthy remote (REM) samples. 16S rDNA clone libraries were prepared from DNA amplified directly from nucleic acid extracts using the eubacterial primers pA/pH'. 450 bp sequences (between nucleotide positions 478 and 928 corresponding to Escherichia coli numbering) were obtained using the eubacterial primer $\mathrm{pE}^{\prime}$. Where BLAST analysis showed a similarity of $\geq 97 \%$, the nearest relative and accession number are given. Note that $16 \mathrm{~S}$ rDNA sequences with similarities of $<97 \%$ are unlikely to be related at the species level (Stackebrandt \& Goebel 1994), and in this case only the division-level identification is shown. \% similarity: similarity to the nearest relative according to BLAST analysis

\begin{tabular}{|c|c|c|}
\hline Clone no. & Nearest phylogenetic relative, description and accession no. & similarity \\
\hline \multicolumn{3}{|c|}{$\alpha$-proteobacterium } \\
\hline AY323175 & $\begin{array}{l}\text { Uncultured } \alpha \text {-proteobacterium associated with healthy tissues of Montastraea annularis } \\
\text { colonies with white plague (AF473961) }\end{array}$ & 99 \\
\hline AY323176 & $\begin{array}{l}\text { Uncultured } \alpha \text {-proteobacterium associated with healthy tissues of } M \text {. annularis colonies with } \\
\text { white plague (AF473961) }\end{array}$ & 98 \\
\hline AY323177 & $\begin{array}{l}\text { Uncultured } \alpha \text {-proteobacterium associated with diseased tissues of } M \text {. annularis colonies } \\
\text { with white plague (AF544897) }\end{array}$ & 100 \\
\hline AY323178 & Uncultured $\alpha$-proteobacterium (AB074693) & 98 \\
\hline AY323179 & $\alpha$-proteobacterium & 89 \\
\hline AY323180 & Uncultured $\alpha$-proteobacterium (AY162053) & 97 \\
\hline AY323181 & Uncultured $\alpha$-proteobacterium (AB074693) & 98 \\
\hline AY323182 & Glacial Ice $\alpha$-proteobacterium (AF479378) & 99 \\
\hline AY323184 & Unidentified marine eubacterial (AF159652) & 98 \\
\hline AY323185 & $\begin{array}{l}\text { Uncultured } \alpha \text {-proteobacterium associated with diseased tissues of } M \text {. annularis colonies } \\
\text { with white plague (AF544902) }\end{array}$ & 100 \\
\hline AY323186 & $\begin{array}{l}\text { Uncultured } \alpha \text {-proteobacterium associated with diseased tissues of } M \text {. annularis colonies } \\
\text { with white plague (AF544897) }\end{array}$ & 99 \\
\hline AY323187 & $\alpha$-proteobacterium & 91 \\
\hline AY323188 & $\begin{array}{l}\text { Uncultured } \alpha \text {-proteobacterium associated with diseased tissues of Diploria strigosa } \\
\text { colonies with black band disease (AF473913) }\end{array}$ & 99 \\
\hline AY323189 & $\begin{array}{l}\text { Uncultured } \alpha \text {-proteobacteria associated with diseased tissues of } M \text {. annularis colonies with } \\
\text { white plague (AF544897) }\end{array}$ & 100 \\
\hline \multicolumn{3}{|c|}{$\beta$-proteobacteria } \\
\hline AY323190 & Bromate-reducing $\beta$-proteobacteria (AF442523) & 98 \\
\hline AY323191 & Uncultured $\beta$-proteobacteria (AF280842) & 99 \\
\hline \multicolumn{3}{|c|}{$\delta$-proteobacteria } \\
\hline AY323192 & Unidentified $\delta$-proteobacteria & 90 \\
\hline AY323193 & Unidentified $\delta$-proteobacteria & 93 \\
\hline \multicolumn{3}{|l|}{ Firmicutes } \\
\hline AY323194 & Uncultured earthworm firmicute (AY154489) & 99 \\
\hline AY323195 & $\begin{array}{l}\text { Uncultured firmicute associated with diseased tissues of } D \text {. strigosa colonies with black } \\
\text { band disease (AF473937) }\end{array}$ & 98 \\
\hline AY323196 & $\begin{array}{l}\text { Uncultured firmicute associated with diseased tissues of } M \text {. annularis colonies with black } \\
\text { band disease (AF473969) }\end{array}$ & 99 \\
\hline \multicolumn{3}{|c|}{ Actinomycetes } \\
\hline AY323197 & Uncultured Rubrobacteridae (AY150888) & 98 \\
\hline
\end{tabular}


Table 2. Acropora palmata. Uncultured bacterial 16S rDNA sequences from 2 independent samples of diseased tissue (DIS). See Table 1 for details

\begin{tabular}{|c|c|c|}
\hline Clone no. & Nearest phylogenetic relative, description and accession no. & $\%$ similarity \\
\hline \multicolumn{3}{|c|}{$\alpha$-proteobacterium } \\
\hline AY323132 & $\alpha$-proteobacterium & 92 \\
\hline AY323133 & Uncultured $\alpha$-proteobacterium associated with white plague-diseased corals (AF544900) & 99 \\
\hline AY323134 & $\alpha$-proteobacterium & 89 \\
\hline AY323135 & $\alpha$-proteobacterium & 93 \\
\hline AY323136 & Uncultured $\alpha$-proteobacterium associated with white plague-diseased corals (AF544894) & 98 \\
\hline AY323137 & $\alpha$-proteobacterium & 96 \\
\hline AY323138 & $\alpha$-proteobacterium & 93 \\
\hline AY323139 & Marine $\alpha$-proteobacterium (AY007677) & 98 \\
\hline AY323140 & Uncultured $\alpha$-proteobacterium (AF432337) & 98 \\
\hline AY323141 & $\alpha$-proteobacterium & 96 \\
\hline AY323142 & $\alpha$-proteobacterium & 90 \\
\hline AY323143 & $\alpha$-proteobacterium & 92 \\
\hline AY323144 & Uncultured $\alpha$-proteobacterium (AJ319844) & 97 \\
\hline AY323145 & $\alpha$-proteobacterium & 91 \\
\hline AY323149 & Uncultured $\alpha$-proteobacterium associated with white plague-diseased corals (AF544897) & 100 \\
\hline AY323151 & Roseobacter sp. (AY136124) & 99 \\
\hline AY323152 & $\alpha$-proteobacterium & 96 \\
\hline AY323153 & Uncultured $\alpha$-proteobacteria (AB074693) & 99 \\
\hline AY323154 & Uncultured $\alpha$-proteobacterium associated with black band-diseased corals (AF473978) & 99 \\
\hline AY323146 & $\alpha$-proteobacterium & 96 \\
\hline AY323147 & $\alpha$-proteobacterium & 96 \\
\hline AY323148 & Uncultured $\alpha$-proteobacterium associated with white plague-diseased corals (AF544896) & 99 \\
\hline \multicolumn{3}{|c|}{$\beta$-proteobacteria } \\
\hline AY323155 & Bromate-reducing $\beta$-proteobacteria (AF442523) & 99 \\
\hline \multicolumn{3}{|c|}{$\delta$-proteobacteria } \\
\hline AY323156 & $\delta$-proteobacterium & 92 \\
\hline AY323157 & $\delta$-proteobacterium & 89 \\
\hline AY323158 & $\delta$-proteobacterium & 91 \\
\hline \multicolumn{3}{|l|}{ Firmicutes } \\
\hline AY323159 & Firmicute & 96 \\
\hline AY323160 & Firmicute & 96 \\
\hline AY323161 & Firmicute & 96 \\
\hline AY323162 & Chlorobium phaeovibrioides (AJ290833) & 97 \\
\hline \multicolumn{3}{|c|}{ Cytophaga-Flexibacter-Bacteroides } \\
\hline AY323165 & CFB bacterium & 95 \\
\hline AY323166 & CFB bacterium & 89 \\
\hline \multicolumn{3}{|c|}{ Planctomyces } \\
\hline AY323167 & Planctomycete & 95 \\
\hline AY323168 & Planctomycete & 89 \\
\hline AY323169 & Planctomycete & 88 \\
\hline \multicolumn{3}{|c|}{ Cyanobacteria } \\
\hline AY323170 & Uncultured marine bacterium (U41090) & 98 \\
\hline AY323171 & Unknown cyanobacterium & 92 \\
\hline AY323172 & Uncultured marine bacterium (U41090) & 98 \\
\hline \multicolumn{3}{|l|}{ Unknown } \\
\hline AY323173 & Unknown eubacterium & 93 \\
\hline AY323174 & Unknown eubacterium & 90 \\
\hline
\end{tabular}

in REM samples compared to 40 in DIS samples from 95 clones. Only $4(10 \%)$ of the ribotypes identified in the DIS samples were also identified in REM samples, indicating a fundamental shift in the bacterial community structure between healthy and diseased states. The sequences recovered from Acropora palmata colonies with no signs of WBD (REM) were predominantly identified as members of the $\alpha$-proteobacteria
$(63 \%), \quad$ Firmicutes $(14 \%), \delta$-proteobacteria $(9 \%)$, $\beta$-proteobacteria (9\%) and Actinomycetes (5\%). The predominant bacteria found associated with tissues at the disease lesion boundary of infected colonies (DIS) were also $\alpha$-proteobacteria (55\%), Firmicutes (10\%), $\delta$-proteobacteria $(7.5 \%)$ and $\beta$-proteobacteria $(2.5 \%)$. However, there were also representatives of the Planctomycetes $(7.5 \%)$, Cyanobacteria (7.5\%) and 
Cytophaga-Flexibacter-Bacteroides (CFB) group (5\%) in the DIS samples which were not identified in REM samples (Fig. 2). Two novel sequences were identified in diseased tissues that have no close relatives in the NCBI database and could not be identified to division. BLAST analysis showed that of the $14 \alpha$-proteobacteria sequences identified in the REM samples $14 \%$ were found to have no previously identified close neighbours (>97.5\% similarity), and $57 \%$ of the $22 \alpha$-proteobacteria identified in the DIS samples by BLAST analysis had no close neighbours suggesting that they are novel, previously unidentified, species. Six ribotypes from the REM samples have previously been identified in both healthy and white plague (WP)-like diseased Montastraea annularis colonies (Pantos et al. 2003), and a further 3 ribotypes were previously found associated with black band diseased (BBD) coral (Cooney et al. 2002), suggesting that they are ubiquitous coralassociated bacteria. DIS samples were found to have 5 ribotypes that were highly similar (>98\%) to sequences previously found only in association with BBD and WP-like diseased tissues of other coral species, indicating that a unique bacterial community develops within lesions of different coral diseases. In some cases, similar ribotypes were found in both the DIS (AY323149) and REM (AY323186, AY323189) samples, which are also closely related to a ribotype found in WP-like disease (Pantos et al. 2003). These are likely to be ubiquitous coral-associated or marine bacteria from the surrounding environment.

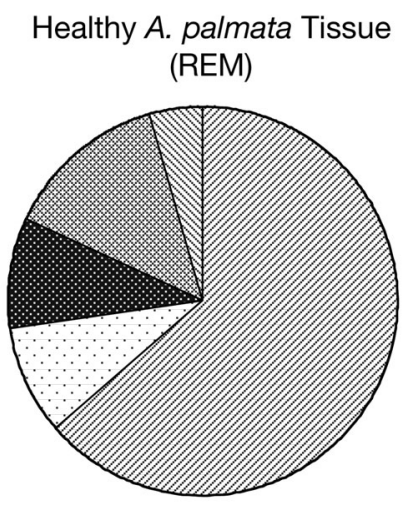
(DIS)

\section{Q-proteobacteria}

๑) $\beta$-proteobacteria

$\delta$-proteobacteria

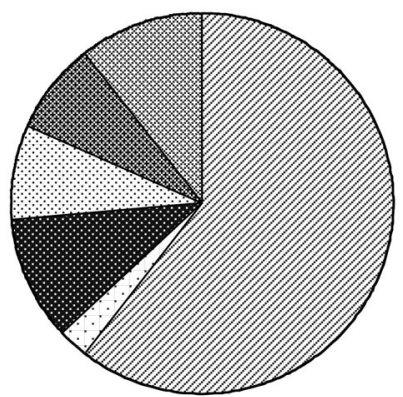

Planctomycetes

\section{Cyanobacteria 图 Firmicutes}

Actinomycetes

Fig. 2. Acropora palmata. Division-level diversity of the partial 16S rDNA bacterial sequence comprising clone libraries associated with 2 samples from healthy tissues (REM) and 2 samples from the WBD disease lesion boundary (DIS). Division-level microbial diversity was calculated by dividing the number of unique sequences in each bacterial division by the total number of distinct sequences present in the clone libraries (REM: $\mathrm{n}=22$; DIS: $\mathrm{n}=40$ )

\section{Profiling bacterial diversity across the disease lesion interface}

Changes in the 16S rRNA gene sequence diversity across the disease lesion interface from apparently healthy tissues of diseased colonies (CON) to tissues at the lesion interface (DIS) and the exposed skeleton (SKEL) were compared with non-diseased coral (REM) using DGGE. A greater diversity of DGGE banding was present in DIS samples than in REM samples (Fig. 3) indicating a greater bacterial diversity in DIS samples, consistent with the findings of clone library formation and BLAST analysis for these 2 samples.

DGGE profiles of the REM samples showed the presence of 5 bands in both samples (Fig. 3, bands 1 to 5). A similar level of diversity was seen in the profiles of CON samples (Fig. 3, Lanes 3 to 5) but the profiles were more variable and few similar sequences exist between the profiles of the CON and REM samples. A highly diverse banding pattern was seen in SKEL samples (Fig. 3, Lanes 10 \& 11), with a high degree of similarity between samples. Some of the common bands could also be seen in the profiles of the other sample types. DIS samples (Fig. 3, Lanes 6 to 9 and Fig. 4, Lanes 3 to 6) showed high levels of diversity with few similar bands appearing in profiles of other sample types. Three bands (Fig. 4, bands 3 to 5) were

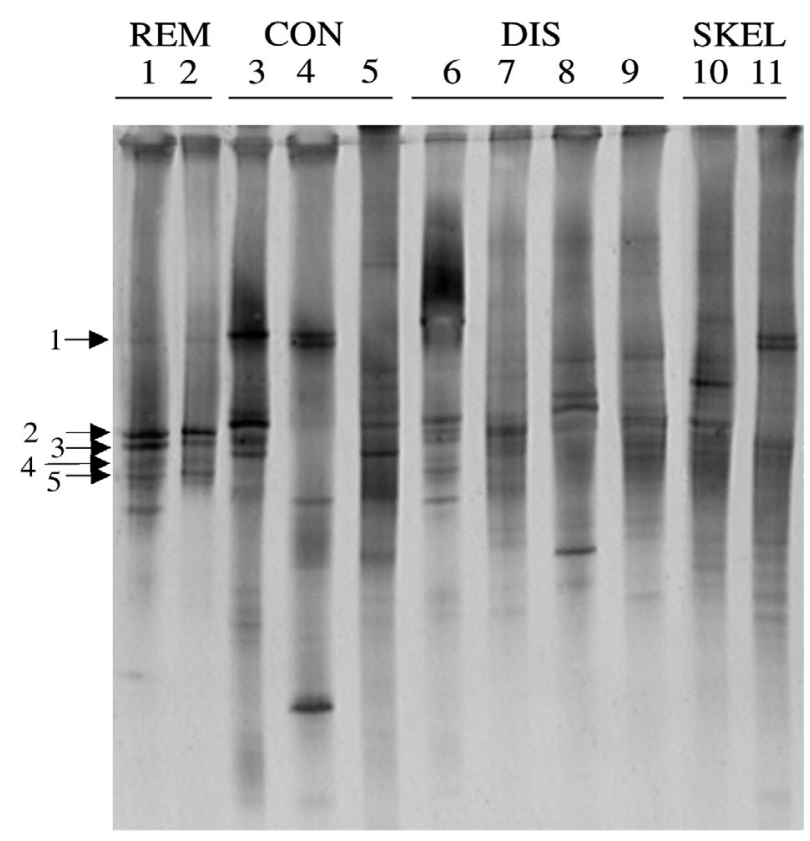

Fig. 3. Acropora palmata. DGGE profile of 16S rDNA fragments from (Lanes 1 to 2) healthy colonies (REM); (Lanes 6 to 9) WBD-affected corals, including diseased coral tissues at the lesion boundary (DIS); (Lanes 3 to 5) apparently healthy tissues from the diseased colony (CON); and (Lanes 10 to 11) exposed skeleton (SKEL). Each lane represents a sample taken from a separate coral colony. Specific bands (1-5); see text 


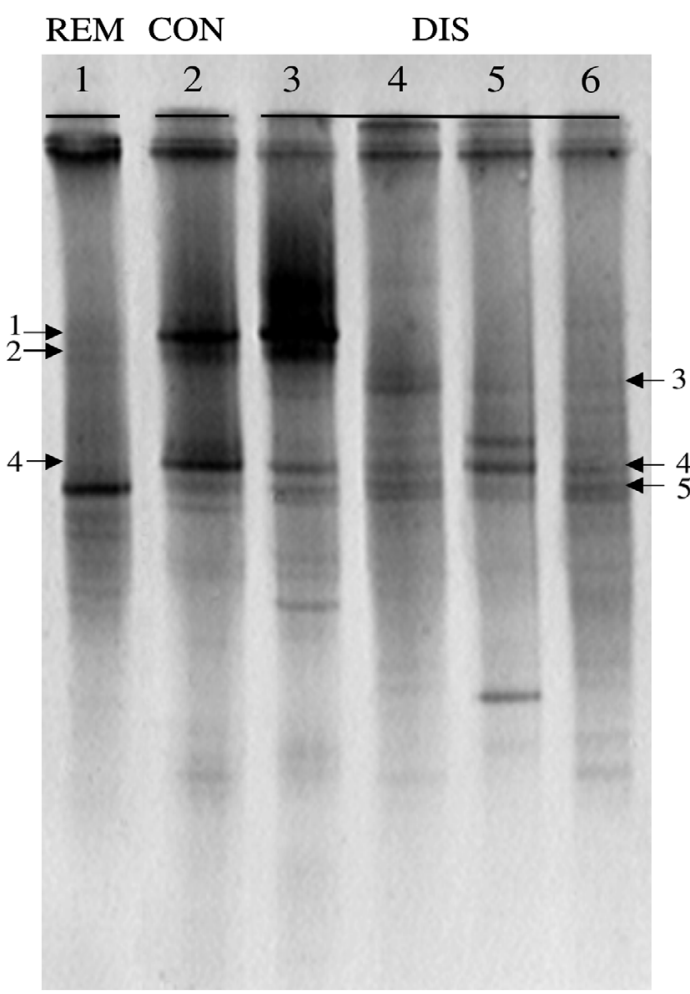

Fig. 4. Acropora palmata. DGGE profile of 16S rDNA fragments from (Lane 1) non-diseased samples (REM); (Lane 2) apparently healthy tissue from diseased colonies (CON); and (Lanes 3 to 6 ) disease lesion tissues from coral colonies with WBD (DIS). Replicate samples were taken from separate coral colonies. Specific bands $(1-5)$; see text

found consistently in all 4 DIS samples. Band 4 was also found consistently in CON but not in REM samples (Figs. $3 \& 4$ ). Several other faint bands were also found to be common across samples. Some of these faint bands can also be seen in the profiles of the CON tissues, but are absent from the REM. Differences between the profiles of the REM and CON samples suggest that the bacterial community structure associated with the intact apparently healthy tissues in advance of the band on diseased colonies has been substantially altered from the community associated with the tissues of non-diseased colonies. Subsequent shifts in the bacterial community profiles of DIS compared with CON tissues ahead of the band suggests that there is a further shift in community structure at the lesion interface.

\section{DISCUSSION}

Bacterial communities of healthy Acropora palmata colonies were distinct from those with WBD. Bacterial sequence diversity associated with healthy A. palmata colonies was lower than that previously seen in other coral species using similar methods (Rohwer et al. 2001, Cooney et al. 2002, Frias-Lopez et al. 2002, Pantos et al. 2003), which may be due to stronger antibiotic properties of the Acroporidae (Koh 1997). A change in the bacterial community of the whole colony occurs when the coral is infected, including tissues that appear healthy, several $\mathrm{cm}$ away from the active lesion. These results are consistent with a previous study on the bacterial community changes associated with Montastraea annularis due to a WP-like disease (Pantos et al. 2003) and reinforce the fact that apparently healthy tissues of infected colonies should not be used as a control reference.

The presence of several DGGE bands within REM samples and their apparent absence from diseased samples suggests that specific bacteria-coral associations may exist that are disrupted when infected. Differences between the DGGE profiles of REM samples of Montastraea annularis (Pantos et al. 2003) and Acropora palmata (Fig. 3) may indicate coral speciesspecific bacterial associations (Rohwer et al. 2001, Rohwer et al. 2002). At the onset of disease, beneficial relationships may be lost or compromised. The loss of protection and subsequent changes in the bacterial community and onset of disease have been observed in other systems (Kim et al. 2001, McNaught \& MacFie 2001, Riquelme et al. 2000). The methods described here may therefore provide a useful screening tool for identifying environmental stress and susceptibility to disease before the onset of visible signs.

Previous studies on the bacterial community of WBD-affected corals has concentrated on the surface mucopolysaccharide layers of Acropora cervicornis with WBD Type II and the use of preferential carbon utilisation methods (Ritchie \& Smith 1995). Bacteria with profiles of Vibrio sp. were identified and these were found to increase in number with the onset of disease. Other bacteria similar to Vibrio sp. have also been identified in A. palmata and A. cervicornis with WBD Type I (Peters et al. 1983) but nothing is known of their phylogeny or about how they are involved in the disease process. The use in the current study of direct PCR amplification and sequencing methods made it possible to detect a greater overall level of diversity, although none of the $16 \mathrm{~S}$ rDNA sequences from the WBD (DIS) samples were from the Vibrionacae. No other known coral disease agents were detected (Fig. 5). The absence of vibrios may be due to bias caused by the primers chosen for this study. However, previous studies have shown that these primers are complementary for members of the $\gamma$-proteobacteria, which includes the Vibrionacae (Cooney et al. 2002).

A bacterial ribotype (AY323154), absent from healthy corals, was detected consistently in WBD samples. Phylogenetic analysis of related sequences 


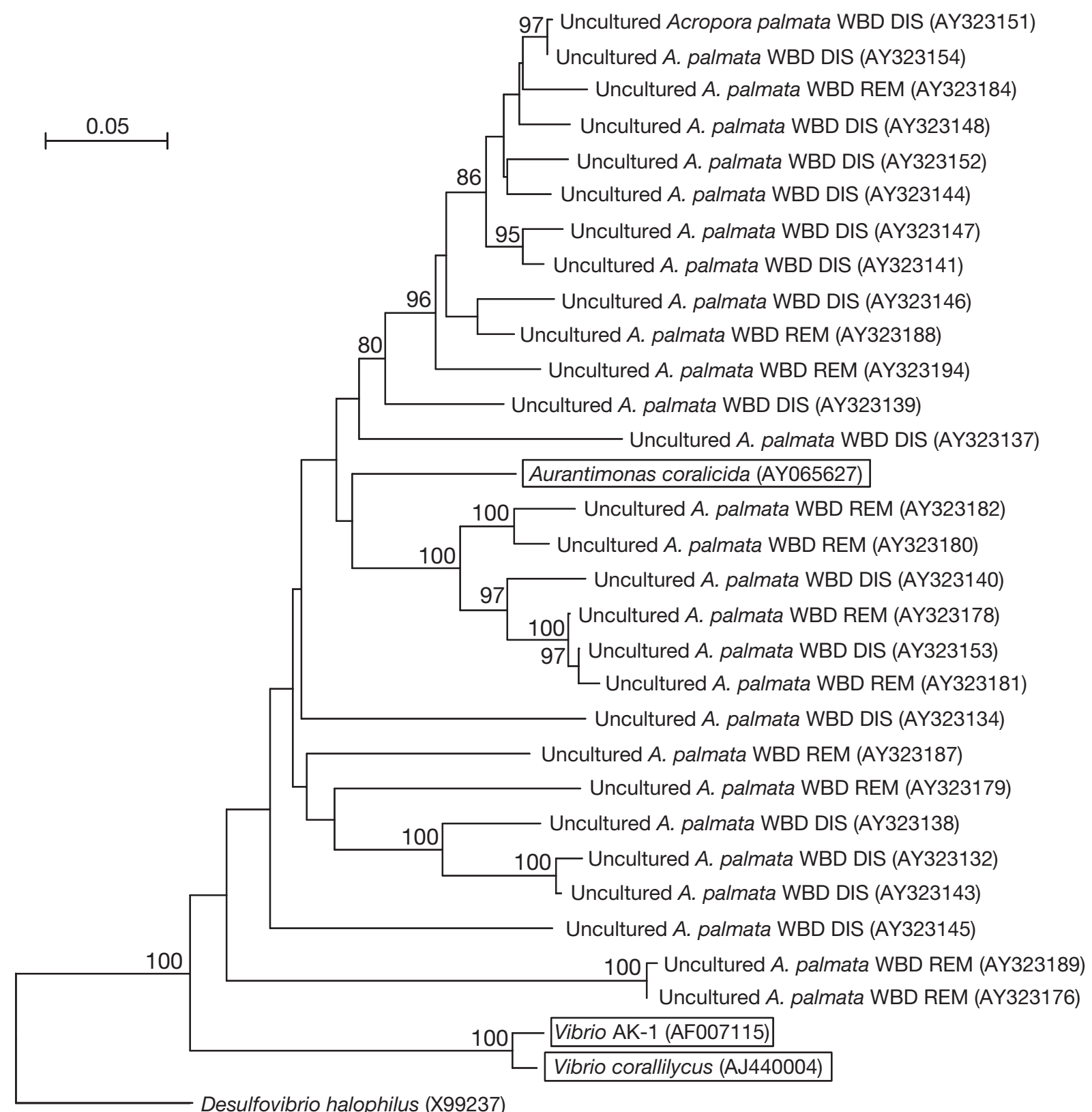

Fig. 5. Neighbour-joining phylogenetic tree based on approximately 500 nucleotides (corresponding to Escherichia coli numbering positions 341 to 928) for the 16S rRNA gene showing the relationships between the uncultured bacteria found in both healthy (REM) and white band disease (WBD)-affected samples (DIS) and bacteria previously identified as causal agents of other coral diseases (AF007115, AJ440004, AY065627). Numbers at the nodes indicate the level of bootstrap support (\%) based on the analysis of 1000 resampled data sets. Scale bar indicates 0.05 substitutions per nucleotide position

from diseased tissue samples showed it to be an $\alpha$-proteobacterium closely related to the causal agent of juvenile oyster disease (JOD) (AF114484) that causes high mortalities of the eastern oyster Crassostrea virginica in hatcheries (Boettcher et al. 2000) (Fig. 6). Similar, but not identical ribotypes have recently been found in white plague-like diseased (AF544882 and AF544906) and black band-diseased coral tissues
(AF473977 and AF473920) (Cooney et al. 2002, Pantos et al. 2003). These ribotypes were also similar (>97.5\%) to a ribotype (AF544943) identified from a DGGE band that was present in the profiles of all WPdiseased Montastraea annularis tissues but absent from apparently healthy samples. This band was found to correspond to one consistently found in the DGGE profiles of WBD Acropora palmata in the present study 


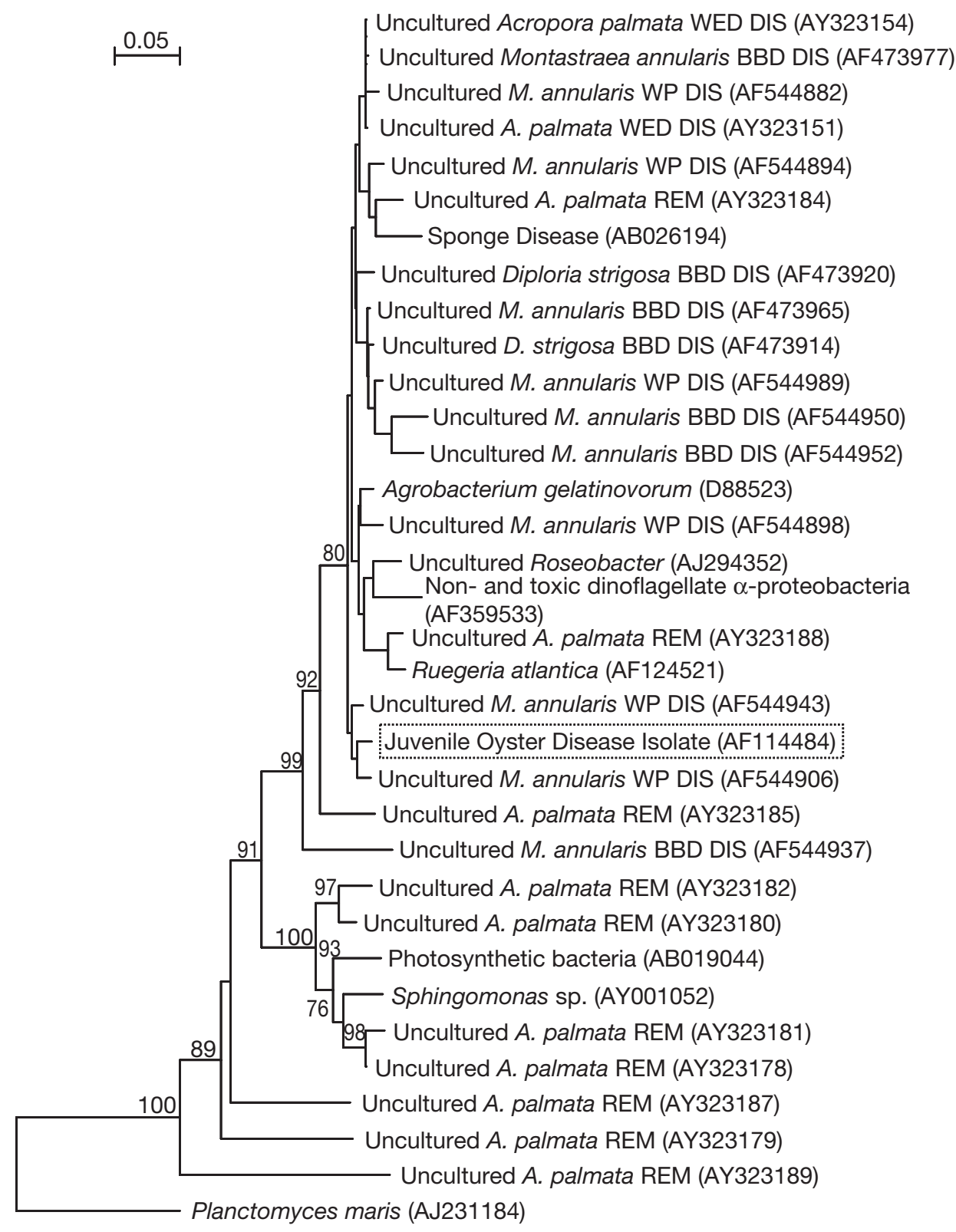

Fig. 6. Neighbour-joining phylogenetic tree based on approximately 500 nucleotides (corresponding to Escherichia coli numbering positions 341 to 928) for the 16S rDNA gene showing the relationships between uncultured $\alpha$-proteobacteria found in healthy (REM) and white band disease (WBD) infected tissue (DIS) and the Crassostrea virginica small pink (CVSP)-bacterium identified as the causal agent of juvenile oyster disease (JOD), and other $\alpha$-proteobacteria associated with white plague (WP)-like and black band disease (BBD) infected corals (Cooney et al. 2002, Pantos et al. 2003). Numbers at the nodes indicate the level of bootstrap support (\%) based on the analysis of 1000 resampled data sets. Scale bar indicates 0.05 substitutions per nucleotide position

(Fig. 4, band 4). Two other ribotypes identified from the A. palmata DIS samples were also found to be similar to $\alpha$-proteobacteria identified from WP-diseased $M$. annularis tissues (AF544894). These sequences were also found to be similar to another sequence identified from the band consistently found in $M$. annularis DIS samples (AF544945) (Fig. 4, band 4) mentioned earlier. These and other sequences identified from DIS sam- ples are closely related to a group of $\alpha$-proteobacteria, involved in other diseases of marine organisms. Whether this closely related group of bacteria are causal agents of the coral diseases remains to be tested, but their consistent appearance in the lesions and absence in healthy corals suggests that they are more than opportunistic invaders and clearly warrant further study. 
Acknowledgements. This research was funded by a grant from the Natural Environment Research Council UK (GR3/11985).

\section{LITERATURE CITED}

Antonius A (1981) The 'band' disease in coral reefs. Proc 4th Int Coral Reef Symp 2:7-14

Aronson RB, Precht WF (2001) White-band disease and the changing face of Caribbean coral reefs. Hydrobiologia 460:25-38

Aronson RB, MacIntyre IG, Precht WF, Murdoch TJT, Wapnick CM (2002) The expanding scale of species turnover events on coral reefs in Belize. Ecol Monogr 72:233-249

Boettcher KJ, Barber BJ, Singer JT (2000) Additional evidence that juvenile oyster disease is caused by a member of the Roseobacter group and colonization of nonaffected animals by Stappia stellulata-like strains. Appl Environ Microbiol 66:3924-3930

Bythell JC, Hillis-Starr ZM, Rogers CS (2000) Local variability but landscape stability in coral reef communities following repeated hurricane impacts. Mar Ecol Prog Ser 204:93-100

Chun RG (1996) Phylogenetic editor, version PHYDIT 3.0. Department of Microbiology, College of Natural Sciences, Seoul National University

Cooney RP, Pantos O, Le Tissier MDA, Barer MR, O'Donnell AG, Bythell JC (2002) Characterization of the bacterial consortium associated with black band disease in coral using molecular microbiological techniques. Environ Microbiol 4:401-413

Edwards U, Rogall T, Blocker H, Emde M, Bottger EC (1989) Isolation and direct complete nucleotide determination of entire genes - characterization of a gene coding for 16Sribosomal RNA. Nucleic Acids Res 17:7843-7853

Filatov D (2001) Processor of sequences, Version 2.7 beta. School of Biosciences, University of Birmingham

Fredricks DN, Relman DA (1996) Sequence-based identification of microbial pathogens: a reconsideration of Koch's postulates. Clin Microbiol Rev 9:18-33

Frias-Lopez J, Zerkle AL, Bonheyo GT, Fouke BW (2002) Partitioning of bacterial communities between seawater and healthy, black band diseased, and dead coral surfaces. Appl Environ Microbiol 68:2214-2228

Gladfelter WB (1982) White-band disease in Acropora palmata-implications for the structure and growth of shallow reefs. Bull Mar Sci 32:639-643

Jukes TH, Cantor CR (1969) Evolution of protein molecules. In: Munro HN (ed) Mammalian protein metabolism, Vol 3. Academic Press, New York

Kim SW, Peck KR, Jung SI, Kim YS, Kim S, Lee NY, Song JH (2001) Pseudomonas aeruginosa as a potential cause of antibiotic-associated diarrhea. J Korean Med Sci 16: $742-744$

Koh EGL (1997) Do scleractinian corals engage in chemical warfare against microbes? J Chem Ecol 23:379-398

McCarthy C (1996) Chromas, version 1.2. School of Biomolecular and Biomedical Science, Griffith University, Brisbane

Submitted: September 15, 2004; Accepted: July 2, 2005
McNaught CE, MacFie J (2001) Probiotics in clinical practice: a critical review of the evidence. Nutr Res 21:343-353

Pantos O, Cooney RP, Le Tissier MDA, Barer MR, O'Donnell AG, Bythell JC (2003) The bacterial ecology of a plaguelike disease affecting the Caribbean coral Montastrea annularis. Environ Microbiol 5:370-382

Peters EC (1993) Diseases of other invertebrate phyla: Porifera, Cnidaria, Ctenophora, Annelida, Echinodermata. In: Couch JA, Fournie JW (eds) Pathobiology of marine and estuarine organisms. CRC Press, Boca Raton, p 393-449

Peters EC, Oprandy JJ, Yevich PP (1983) Possible causal agent of white band disease in Caribbean acroporid corals. J Invertebr Pathol 41:394-396

Relman DA (1998) Detection and identification of previously unrecognized microbial pathogens. Emerg Infect Dis 4: 382-389

Riquelme C, Araya R, Escribano R (2000) Selective incorporation of bacteria by Argopecten purpuratus larvae: implications for the use of probiotics in culturing systems of the Chilean scallop. Aquaculture 181:25-36

Ritchie KB, Smith GW (1995) Preferential carbon utilization by surface bacterial communities from water mass, normal, and white-band diseased Acropora cervicornis. Mol Mar Biol Biotechnol 4:345-352

Ritchie KB, Smith GW (1998) Type II white-band disease. Rev Biol Trop 46:199-203

Rohwer F, Breitbart M, Jara J, Azam F, Knowlton N (2001) Diversity of bacteria associated with the Caribbean coral Montastraea franksi. Coral Reefs 20:85-91

Rohwer F, Seguritan V, Azam F, Knowlton N (2002) Diversity and distribution of coral-associated bacteria. Mar Ecol Prog Ser 243:1-10

Rölleke S, Muyzer G, Wawer C, Wanner G, Lubitz W (1996) Identification of bacteria in a biodegraded wall painting by denaturing gradient gel electrophoresis of PCR-amplified gene fragments coding for 16S rRNA. Appl Environ Microbiol 62:2059-2065

Rölleke S, Witte A, Wanner G, Lubitz W (1998) Medieval wall paintings - a habitat for Archaea: identification of Archaea by denaturing gradient gel electrophoresis (DGGE) of PCR-amplified gene fragments coding for 16S rRNA in a medieval wall painting. Int Biodeterior Biodegrad 41:85-92

Saitou N, Nei M (1987) The neighbor-joining method - a new method for reconstructing phylogenetic trees. Mol Biol Evol 4:406-425

Singleton DR, Furlong MA, Rathbun SL, Whitman WB (2001) Quantitative comparisons of 16S rRNA gene sequence libraries from environmental samples. Appl Environ Microbiol 67:4374-4376

Stackebrandt E, Goebel BM (1994) A place for DNA-DNA reassociation and $16 \mathrm{~S}$ ribosomal-RNA sequence-analysis in the present species definition in bacteriology. Int J Syst Bacteriol 44:846-849

Van de Peer Y, De Wachter R (1994) TREECON for Windows: a software package for the construction and drawing of evolutionary trees for the Microsoft Windows environment. Comput Appl Biosci 10:569-570

Proofs received from author(s): January 30, 2006 